\title{
"Muecas para escribientes": reflexiones en torno a la cuentística de Virgilio Piñera
}

\author{
Cristina PÉREZ MÚGICA \\ Universidad de Salamanca
}

\begin{abstract}
RESUMEN
Los conceptos de excentricidad y periferia son frecuentes en los estudios latinoamericanos, donde han llegado a constituir categoría de estudio y canonización. El cubano Virgilio Piñera responde bien a tales etiquetas, pues rehúye adscripciones estilísticas o generacionales para forjar su inconfundible idioma literario. Este halla fundamento en diversas nociones de absurdo, grotesco, existencialismo y neofantasía, herramientas que desafían toda lógica racional para ofrecer alternativas epistemológicas al individuo moderno. A partir de aquí, confiere papel fundamental a la carne, en tanto retórica que obvia el binomio alma-cuerpo erigiendo este último en instrumento de libertad o resistencia a la alienación. En este sentido, y pese a su condición disidente, Piñera constituye perfecto representante de cierto espíritu epocal.
\end{abstract}

Palabras Clave: Virgilio Piñera, Modernidad, absurdo, neofantasía, retórica de la carne.

\section{"Grins for clerks": reflections on the short stories of Virgilio Piñera}

\begin{abstract}
Concepts of eccentricity and outskirts are frequent at Latin American studies, where they have come to constitute a category of study and canonisation. Cuban Virgilio Piñera reflects well this labels, as he avoids neither stylistic nor generational ascriptions to forge his unmistakable literary language. This finds its grounds on different notions of absurdity, grotesque, existentialism and neofantasy, tools that defy every rational logics to offer epistemological alternatives to modern man. From here on, he confers a fundamental role to the flesh, in the sense that it is a rhetoric that obviates the soul/body binomial, thus setting the body as an instrument of freedom or resistance to alienation. In this sense, and despite of his condition as a dissident, Piñera constitutes a perfect representative of a kind of a certain epoch's spirit.
\end{abstract}

Keywords: Virgilio Piñera, Modernity, absurdity, neofantasy, retoric of the flesh.

SUMARIO: 1. Introducción. 2. Virgilio: disidente hijo de su tiempo. 3. Las contradicciones de lo real: neofantasía y absurdo. 4. La llamada de la carne. 5. Un huequito para respirar. 6. Conclusión. 7. Bibliografía. 
Hago el llamado siguiente a los sanos: ¡por Dios, no leáis únicamente esos sempiternos libros sanos, acercaos también a la literatura dizque malsana de la que podéis sacar tamaña enseñanza!

Robert Walser, Der Räuber

\section{Introducción}

Loco, excéntrico, marginal... son calificativos frecuentes en los acercamientos al cubano Virgilio Piñera. De hecho, en el prólogo a Cuentos completos, su amigo Antón Arrufat parte de una reflexión semántica sobre tales conceptos: "Antes de sentarme a escribir estas páginas, una palabra me daba vueltas. Caminando por mi casa me la repetí varias veces, hasta sentir en la boca su sabor amargo. La busqué en los diccionarios que tengo a mano [...]. Aparecían las palabras marginal, marginado, pero faltaba el significado con que solemos usarlas en la sociedad actual" (Arrufat, 1999: 11).

Arrufat busca establecer ese peculiar sentido periférico que rige el universo piñeriano, generando personajes y territorios alucinados donde tiempo y espacio se despliegan merced a una lógica tan irreprochable como perversa. De igual modo, estas reflexiones sobre la cuentística de Piñera se fundamentan en los principios de lo paranoico e inverosímil: intentaremos establecer el alcance y dimensión que alcanzan en su universo literario, teniendo siempre en cuenta el contexto socio-cultural.

\section{Virgilio: disidente hijo de su tiempo}

Para empezar, los más cercanos al autor coinciden en señalar sus tendencias excéntricas y solitarias: Virgilio se sentía incómodo en sociedad y sus maneras podían resultar crudas, cuando no desagradables. Arrufat señala también cierta inclinación al histrionismo combinada con una casi enfermiza timidez (ibíd.: 13). En su opinión, la condición marginal de Piñera fue en similar proporción elegida e impuesta. Así, menciona la miseria económica que lo asfixió durante casi toda su vida, las dificultades derivadas de su condición sexual y los complejos procesos políticos que le tocó vivir.

En efecto, la corrupción institucional y la parálisis socio-cultural características de los regímenes posteriores a la Independencia lo llevarían a percibir La Habana como un sepulcro. Más tarde, la esperanza revolucionaría se vio frustrada ante un sistema incapaz de modificar la conservadora política sexual. El autor quedó entonces condenado al más penoso aislamiento, enfrentado a la evidencia de que no le dejarían "ni un huequito para respirar".

Sus apuntes autobiográficos resumen a la perfección estas circunstancias. Allí se refiere el descubrimiento infantil de "tres gorgonas" que habrían de empujarlo a los márgenes:

${ }^{1}$ Las cursivas son del texto. 
No bien tuve la edad exigida para que el pensamiento se traduzca en algo más que soltar la baba y agitar los bracitos, me enteré de tres cosas lo bastante sucias como para no poderme lavar jamás de las mismas. Aprendí que era pobre, que era homosexual y que me gustaba el Arte [...]. Claro que no podía saber a tan corta edad que el saldo arrojado por esas tres gorgonas, miseria, homosexualidad y arte, era la pavorosa nada (Piñera, 1990: 23-24).

Tal círculo de miseria, enajenación y angustia absorbe también a sus personajes. La marginación se asume porque no queda otro remedio, aunque se abre la posibilidad de transformar la condición impuesta en opción vital, esgrimiendo sin temor la perversa lógica que de ello resulta. En este sentido, Virgilio y sus criaturas se proclaman excéntricos en sentido literal, es decir, ajenos a todo centro rector.

Lo periférico también define la posición de Piñera en el campo intelectual cubano. En un primer momento, el autor se integra en el grupo Orígenes, pero las preferencias del colectivo no siempre coinciden con sus intenciones. Así, nos encontramos ante un interesante caso de disidencia generacional: no en vano, Virgilio utiliza la misma revista Orígenes para cuestionar la poética de importantes coetáneos.

En realidad, la búsqueda piñeriana apenas se corresponde con el proyecto origenista. Su estima por la Palabra resulta dudosa, pues cancela todo potencial metafísico presentando el lenguaje verbal como agente alienante o reducto fosilizado. Por otra parte, y frente a la conocida orientación teológica del grupo, construye escenarios angustiosos marcados por la ausencia de sentido o trascendencia. En este marco, acuña un idioma inconfundible que confirma su radical originalidad en el contexto literario del momento.

Otra cuestión a debatir es si lo excéntrico distingue también a Virgilio en el ámbito general de las literaturas latinoamericanas. Antón Arrufat lo afirma con seguridad:

Al lector habitual de literatura latinoamericana, el nombre de Piñera no le es familiar y su obra no ha alcanzado la divulgación de ciertas obras paradigmáticas. Piñera no es un barroco. Su lenguaje es un esfuerzo voluntario -también en estopor encontrar modos de expresión diversos al de los textos barrocos y neobarrocos de América Latina. [...] Si la literatura tuviera caras, la obra de Piñera, tan peculiar, vendría a ser la otra cara de la literatura latinoamericana, formada por unos cuantos marginados [...]. Si el futuro lector de Piñera se halla familiarizado con la lectura de Cortázar o Carpentier, pronto se dará cuenta, tal vez desde la línea inicial, de que ninguna semejanza encontrará entre ellos y Piñera. Son escrituras diametralmente opuestas. (Arrufat, 1999: 30-31)

Arrufat menciona confusiones habituales en la recepción de narrativas hispanoamericanas tras el llamado "boom". En efecto, suele suponerse que la literatura del subcontinente tiende por naturaleza a lo barroco y tropical. Al canonizar los estilos de alta temperatura, que proceden por sobreabundancia y acumulación, los autores inclinados a la carencia quedan recluidos en una suerte de vacío identitario. Estas conclusiones resultan precipitadas e incompletas. En primer lugar, la teoría neobarroca sólo pertenece a ciertos autores como Lezama o Carpentier, por lo que no 
resulta funcional como etiqueta genérica. Por otra parte, diversos grados de derroche y contención pueden dar cauce a actitudes y preocupaciones muy similares.

En este sentido, la condición marginal de la obra piñeriana obedece a condicionamientos externos: deficiencias en la recepción crítica, inclinaciones del público lector y preferencias editoriales. Si prescindimos de estos elementos, cabe afirmar que su propuesta se inserta con absoluta coherencia en el contexto epocal. Veámoslo.

En primer lugar, las tendencias literarias surgidas en América Latina durante el siglo XX, se llamen realismo mágico, neofantasía o escritura del absurdo, pueden integrarse en esa dialéctica de crisis-institucionalización que condiciona el discurso racional moderno.

En Europa, por ejemplo, diversas corrientes filosóficas y estéticas proceden al cuestionamiento de todo asidero metafísico, social e identitario. Tal dinámica subraya la impotencia de la razón como instrumento universal de orden y conocimiento: los preceptos ilustrados no ofrecen respuesta a inquietudes últimas ni pueden garantizar un futuro benéfico y feliz. Los efectos de tal conciencia crecerán en forma proporcional al progreso tecnológico y urbano, generando el ambiente de crispación y violencia que desembocará en dos guerras mundiales. ${ }^{2}$

América Latina recoge la problemática occidental, insertando en el marco de crisis sus específicos dilemas identitarios. Tal como señala Ambrosio Fornet, semejante combinación convierte la literatura en testimonio de absurdo e irracionalidad: "En Europa: campos de concentración, hornos crematorios, billeteras de piel de judío, caos. Luego Hiroshima: vimos aquella silueta humana retratada sobre el pavimento por el fogonazo de la explosión atómica sin sospechar que ya no la olvidaríamos [...]. Esa fue la doble atmósfera que respiramos, la de nuestro país, la de nuestra época [...]" (cit. en Aguilú de Murphy: 15).

La crisis del racionalismo se agudiza en espacios que desde su encuentro traumático con lo europeo habían desafiado cualquier modelo absoluto. La asunción del idioma occidental siempre resultó problemática, al superponerse este sobre realidades inéditas. Ello explica el empeño de ciertos autores por fracturar el discurso ilustrado en lenguajes más libres e integradores: dialogan con grandes innovaciones europeas sin olvidar que su realidad espera respuestas específicas. Piñera se incorpora a tal contexto afrontando toda quiebra ontológica para ofrecer respuestas al individuo angustiado. De ahí que afirme:

no soy del todo existencialista ni del todo absurdo. Lo digo porque escribí Electra antes que Las Moscas de Sastre apareciera en libro y escribí Falsa alarma antes que Ionesco publicara y representara su Soprano Clava. Más bien pienso que todo esto estaba en el ambiente $y$ aunque viviera en una isla desconectada del continente

\footnotetext{
${ }^{2}$ Sobre estas cuestiones véanse Marshall Berman y Matei Calinescu.
} 
cultural, con todo, era un hijo de mi época al que los problemas de dicha época no podian pasarle desapercibidos. (cit. en ibid: 26$)^{3}$

\section{Las contradicciones de lo real: neofantasía y absurdo}

Considerando lo dicho, señalaremos filiaciones más concretas para la escritura piñerana. Para empezar, la crítica suele invocar neofantasía y absurdo, categorías que coinciden en explorar los márgenes del sistema racional. Ambos modelos, además, establecen interesantes conexiones con los programas surrealista y existencialista.

Lo fantástico ha sido objeto de múltiples especulaciones, sin que exista acuerdo definitivo sobre su naturaleza o funcionamiento. No obstante, en nuestro caso resulta interesante acudir al modelo de "neofantasía" propuesto por Jaime Alazraki. Según este crítico, la fantasía tradicional suele preparar el ambiente para que la irrupción del suceso inexplicable produzca sobresalto y terror, mientras que los textos neofantásticos introducen desde el principio lo inverosímil para, a partir de ahí, naturalizarlo. ${ }^{4}$ En este sentido, no persiguen suscitar miedo sino inquietud en un lector obligado a cuestionarse su noción de realidad. Por otra parte, lo neofantástico conlleva cierta propuesta ética: el escritor traduce dilemas existenciales convirtiendo su escritura en antídoto contra todo conformismo. Ello conduce a un tercer rasgo, relacionado con la formación de autores que suelen escribir bajo influencia de teorías psicoanalíticas, existencialistas y surrealistas. ${ }^{5}$

También conviene matizar el papel desempeñado por lo sobrenatural. Según Todorov, cualquier efecto fantástico procede por intromisión violenta de algún suceso en apariencia ajeno a leyes racionales. Por ello su eficacia queda vinculada a la ambigüedad: el marco fantástico se construye mientras el lector vacila entre una explicación lógica, pero improbable, y una razón sobrenatural contraria al orden establecido. Al optar por una de estas posibilidades, ingresamos en categorías diferentes: lo extraño, en el primer caso, y lo maravilloso, en el segundo. ${ }^{6}$ Tal principio de duda sitúa lo fantástico en los márgenes del proceso cognoscitivo y confiere importantes responsabilidades al lector.

Los aspectos comentados resultan fundamentales en la construcción de cuentos piñerianos. Así, destaca el recurso a la alegoría o metáfora epistemológica, que Alazraki considera característica de lo neofantástico. Este mecanismo convierte lo sobrenatural en modo epistemológico. Así, una metamorfosis hombre-escarabajo subrayaría la capacidad alienante del orden burocrático. En línea similar, el personaje

${ }^{3}$ El destacado es nuestro.

4 La metamorfosis de Kafka constituye ejemplo paradigmático de tal procedimiento. También resulta elocuente el comienzo del cuento piñeriano "La carne": "Sucedió con gran sencillez, sin afectación" (Piñera, 1999: 38).

${ }^{5}$ Cfr. Jaime Alazraki, “¿Qué es lo neofantástico?”, en Roas: 265-282.

${ }^{6}$ Cfr. Tzvetan Todorov, "Definición de lo fantástico" y "Lo extraño y lo maravilloso", en Roas: 47-81. 
de Virgilio que da a luz su propia muerte dibuja una parábola existencial sobre la condición humana. ${ }^{7}$

También resulta fundamental el sujeto narrativo. Con frecuencia, se asume el discurso de tipos enajenados y paranoicos, cuya vida transcurre en márgenes sociales. Ello obliga a aceptar perspectivas excéntricas como punto de partida. Así ocurre en el texto piñeriano "Unos cuantos niños", que, en apariencia, describe un suceso sobrenatural: el protagonista se introduce en el estómago de un perro para despistar a sus perseguidores. No obstante, debemos preguntarnos hasta qué punto podemos confiar en un narrador que abre su relato con esta confesión:

Dos palabras a manera de prólogo: me gustan los niños de pocos meses de nacidos. No se piense a la ligera que soy anormal, un nuevo Gilles de Rais [...]. Soy un hombre de su casa, un empleado del Estado que cumple sus deberes. No vivo en lugares apartados, no frecuento gente de mal vivir, pago mis impuestos, nunca me he visto en líos con la justicia; en una palabra, soy un buen ciudadano. Pero me gustan los niños. Para comérmelos (sic). (Piñera, 1999: 196)

Discursos así imponen una reinterpretación de lo sobrenatural, que ya no se establece por oposición a lo natural. En efecto, la dicotomía tradicional considera la fantasía como ajena a lo real-cotidiano, atribuyéndole meras funciones compensatorias. Los autores como Piñera o Cortázar pretenden desmantelar tal percepción, invitándonos a aceptar lo fantástico como parte integrante y necesaria de la realidad. Así, el argentino propone sustituir el concepto sobrenatural por la sugerente categoría de lo otro, aquello cuya presencia resulta tan innegable como incómoda para el individuo convencional. Virgilio genera sensaciones análogas con su escritura fría, lógica y persuasiva, que recupera discursos recluidos para cuestionar los métodos racionales, introduciendo nociones alternativas de realidad. ${ }^{9}$

En este sentido, se mantiene la percepción surrealista de "lo maravilloso" como "contradicción que aparece en lo real". Estas palabras de Louis Aragon pueden completarse con lo afirmado por Jacques Rigaut: "Lo Maravilloso, lo Fantástico, es menos de lo que se puede esperar. Lo verdadero maravilloso reside en una norma, la razón, por ejemplo, o la sensatez" (cit. en Pariente: 214). Todo ello remite al discurso de la locura que, según explica Foucault en su Histoire de la folie à l'âge classique, existe por y en la razón. ${ }^{10}$ En este sentido, los cuentos piñerianos recogen ese chispazo que provoca la constante fricción entre ambas, enfrentándonos al abismo de lo inseguro y contradictorio.

${ }^{7}$ Nos referimos al cuento "Un parto insospechado".

${ }^{8} \mathrm{La}$ acotación (sic.) pertenece al texto.

${ }^{9}$ Sobre esta cuestión véanse Marta Morello Frosch, "La razón de la locura en las ficciones de Virgilio Piñera" y Vicente Cervera, "La salvación por la locura", pp.29-40 y 65-75, respectivamente.

${ }^{10}$ Cfr. Michael Foucault. 
Lo explicado permite afirmar que existen importantes conexiones entre la neofantasía y el absurdo, pues ambas categorías conducen la cotidianeidad a situaciones límite, invocando lo inverosímil-alegórico. Piñera encaja bien en estos patrones, tal como observa su hermano Humberto: "vuelto siempre contra el mundo, en perpetuo conflicto con él, era la cabal personificación de algo muy en boga desde hace años, es decir, el absurdo" (cit. en Noguerol: 78).

Respecto al vínculo entre absurdo y existencialismo, Piñera conectó ambos modelos con la experiencia de una Cuba "existencialista por defecto y absurda por exceso". Así, en La vida tal cual observa:

El sentimiento de la Nada por exceso es menos nocivo que el sentimiento de la Nada por defecto: llegar a la Nada a través de la Cultura, de la Tradición de la abundancia, del choque de las pasiones, etc. supone una postura vital [...]. Es así que podría decirse de estos agentes que ellos son el "activo" de la Nada. Pero esa Nada, surgida de ella misma, tan física como el nadasol que calentaba a nuestro pueblo de ese entonces, como las nadacasas, el nadaruido, la nadahistoria... nos llevaba ineluctablemente hacia la morfología de la vaca o el lagarto. (Piñera, 1990: 23)

En otro momento, explica su acercamiento a planteamientos absurdistas: "en la época en que escribí Electra meditaba a diario en esto: en medio de tanta confusión, ¿con quién puedo contar? Y la respuesta era la reducción al absurdo: conmigo mismo, y digo reducción al absurdo pues el ser humano que sólo cuenta consigo mismo está atado de pies y manos" (cit. en Aguilú de Murphy: 27).

Tales meditaciones le permiten desarrollar una dramaturgia de factura absurda y tono existencial que precede a las primeras muestras europeas. De forma complementaria, sus cuentos abordan cuestiones fundamentales: fosilización del lenguaje, incomunicación, quiebra identitaria... Todo ello lo inserta en cierta tradición fundamental para la moderna narrativa latinoamericana, tal como explica Francisca Noguerol:

en el cuento hispanoamericano existe una línea de pensamiento absurdista cimentada por numerosos e importantes autores como Macedonio Fernández, Felisberto Hernández, Jorge Luis Borges, Juan José Arreola, Enrique Anderson Imbert, Julio Cortázar, René Avilés Fabila, Marco Denevi, Carlos Béjar Portilla, Augusto Monterroso, Enrique Jaramillo Leví, Julio Matas, Álvaro Menén Desleal, Julio Ricci, Álvaro Menéndez Leal, Cristina Peri Rossi, Luisa Valenzuela o Antonio Skármeta. (Noguerol: 77-78)

En este marco pueden hallarse interesantes claves para acceder a los cuentos piñerianos. Así, Noguerol destaca "la exposición de los aspectos de la sociedad moderna que contribuyen al absurdo", tales como "la deshumanización consecuencia del excesivo énfasis en lo trivial y rutinario, la inversión de valores para servir al denominado progreso y la devaluación que ha sufrido el lenguaje". A partir de aquí, Piñera describe "un mundo enloquecido a través de técnicas que provocan por sí 
mismas el sentimiento del absurdo en el lector". Con ello pretende responder "a la eterna interrogante sobre el sentido de la existencia con una visión irónica y humorística del ser humano, nunca exenta de escepticismo" (ibíd.: 78).

Por tanto, numerosos textos piñerianos responden a premisas existencialistas. Para empezar, podríamos considerar el temor congénito e indefinido que, según Heidegger, signa la conciencia arrojada al vacío. Freud, por su parte, descubre en tal zozobra nociones inconscientes de culpabilidad. Todo ello podría explicar las manías persecutorias que sufre el protagonista de Pequeñas maniobras, así como el innominado temor que ha anulado la existencia del narrador en "El enemigo", un "miedo hacia adentro" que confiere doble valor del título. ${ }^{11}$ En fin, esa misma angustia late en textos como "El que vino a salvarme", cuyo protagonista da "las gracias por venir" a su asesino (Piñera, 1999: 265).

También debemos considerar el principio camusiano del hombre rebelde o Sísifo feliz: según el filósofo francés, la sonrisa irónica y vengativa permite esgrimir cualquier absurdo existencial como modus vivendi. Tal sentido rige las "Ocupaciones raras" propuestas por Cortázar en Historias de cronopios y de famas, así como algunos cuentos breves de Piñera. Por ejemplo, en "La gran escalera del palacio Legislativo" un individuo escapa al vacío existencial recorriendo con extasiada obsesión una escalera. ${ }^{12}$ Por su parte, "El viaje" parodia el arquetipo heroico del viajero: llegada su madurez, el protagonista emprende una absurda excursión en cochecito de niños, sin destino ni aliciente alguno. Con ello pretende demostrar "cuán equivocado estaba yo al esperar algo de la vida": semejante revelación invalida la clásica parábola del trayecto iniciático (ibíd.: 108). ${ }^{13}$

Otros textos subrayan la imposibilidad de lograr comunicación efectiva y sincera, confirmando la devaluación del lenguaje como herramienta social. "Las protestas de cortesía y las frases de estilo" mencionadas en "El cambio", así como la sobreabundancia de convenciones, conducen a diálogos absurdos y vacíos de significado (ibid:: 46). ${ }^{14}$ Con frecuencia, el escritor se hace con las armas del enemigo, reiterando tales clichés hasta la náusea: una suerte de puesta en abismo que confirma su vacuidad. Así ocurre en "La Locomotora", donde se comenta "lo riesgoso de esta aventura que consiste en saber que aquella locomotora que avanza

${ }^{11}$ El narrador teme a sus congéneres, mientras la culpa lo empuja a considerarse enemigo de la humanidad. Tal sentimiento podría expresarse en términos similares a los manejados por César Vallejo para Los heraldos negros: conciencia de no entregarse o no estar donde lo necesitan.

${ }^{12}$ Como en las conocidas "Instrucciones" de Cortázar, la escalera se constituye en símbolo del absurdo.

${ }^{13}$ Se detectan ciertos tintes nietzscheanos en esta llamada a la acción sin expectativa $u$ objetivo. Piñera sintetiza tales principios en el poema de 1961 "Un bamboleo frenético".

${ }^{14}$ En este texto, la pérdida de lengua y ojos proporciona una existencia dichosa a dos parejas de amantes. El argumento recoge una idea básica en el universo piñeriano, donde vista y habla suelen funcionar como pantallas aislantes que impiden todo encuentro comunicativo. 
por un terraplén muy estrecho es la mayor del mundo" (ibíd: 155$).{ }^{15}$ El absurdo comunicativo también afecta al escritor, abocándolo a soledad monologante. "Grafomanía" condena a los literatos por falseadores, veleidosos e insolidarios, propuesta similar a la planteada por Cortázar en "Fin del mundo del fin". En definitiva, como en el poema de Enrique Lihn "Plumifero y vestido de payaso", los grandes gestos literarios devienen simples "muecas para escribientes", de ahí el título elegido para estas reflexiones.

\section{La llamada de la carne}

Hasta ahora hemos procurado contextualizar la producción cuentística de Piñera, estableciendo sus principales líneas de desarrollo. A partir de aquí, nos centraremos en aspectos que le confieren especial originalidad. Adorno y los formalistas rusos establecieron las categorías shock y extrañamiento como definitorias de todo efecto artístico. Con frecuencia, los textos piñerianos erigen tales principios sobre la retórica de la carne, símbolo polivalente que condiciona temas y discurso.

En primer lugar, parece que Virgilio mantiene una compleja y contradictoria relación con su propio cuerpo. Antón Arrufat aporta detalles útiles al respecto:

El centro de la meditación y hasta de la angustia de Piñera no es el alma, sino el cuerpo. [...] Es claro que Piñera no estaba de acuerdo con su cuerpo. Más tarde llamaría a este desacuerdo un real "divorcio". Divorcio que no implica por supuesto matrimonio previo. Esto es indudable: Piñera se consideraba un hombre feo [...]. Si para cualquiera considerarse feo, tener una relación desacordada con su cuerpo, constituye una desdicha, lo es más para un homosexual. El homosexual tiene el mito de la belleza y vive en perenne conquista del cuerpo. En el comercio sexual del mundo, en el erotismo, el cuerpo de Piñera se hallaba en desventaja. Se encontraba preso en una situación realmente paradójica: tener un cuerpo y estar inconforme con él. (Arrufat, 1999: 26)

Por otra parte, esta reflexión carnal contiene claras resonancias epocales, subrayando cierta contradicción heredada del pensamiento judeocristiano: la irresoluble dicotomía cuerpo-alma. La teología occidental establece una imagen fragmentada de la condición humana: el alma resulta depositaria de todo destino trascendente, albergando esencias identitarias, mientras el cuerpo constituye recipiente o cobertura vinculada a lo terrenal-transitorio. Resulta, entonces, que necesidades e inclinaciones carnales nos alejan de nuestra natural morada celestial.

Tal sistema conlleva trágicas paradojas, pues el individuo no tiene constancia del alma, entelequia inaprensible, mientras diversas necesidades corporales gobiernan su diario vivir. Como resultado, la carne se constituye en presencia extraña, cuando no odiada: ente superpuesto a la conciencia, que con sus pulsiones y exigencias

${ }^{15}$ La locomotora funciona también como paradigma absurdo en "El guardagujas" de Juan José Arreola. 
obstaculiza nuestro verdadero destino. Así lo expresa Piñera en su "Discurso a mi cuerpo":

Pero todo aquello era una farsa; sentía que nadie me era más ajeno, extraño o insoportable que tú; [...]. Sí, porque todo te lo llevabas tú; todo te pertenecía y hasta tenías tus sacerdotes en los oficiantes médicos y cirujanos que sobre ti se inclinaban. [...] Y el problema no lo era de enemistad, porque nunca antes hubiéramos participado de amistad; tampoco desligamiento. Sí creo que seamos la contradicción que necesita contradecirse [...]. A veces doy en cavilar si esa especial conformación de las plantas de tus pies no es sino una grave advertencia que impide sea olvidado el principio de que todos vosotros estáis atados al sentido de la tierra; y que vuestra sordera sea la sordera de la tierra. (Piñera, 1990: 35-36) ${ }^{16}$

Tales principios quedan fijados en La carne de René. Françoise Moulin Civil señala al respecto: "Esta novela, habitada obsesiva y contradictoriamente por el dolor y el placer, es la que gobierna gran parte del significado total del resto de su obra narrativa, tanto anterior como posterior, en particular de su cuentística" (Moulin Civil: 43-44). Por su parte, Antón Arrufat entiende que La carne de René, como El siglo de las luces y Paradiso, "representa con cierta exactitud el Bildungsroman", pues "narra la historia de un joven adolescente y su progresivo conocimiento del valor de la vida y del mundo" (Arrufat, 1990: 44).

En este sentido, la iniciación de René quedará signada por el cuerpo y sus significados. Los avatares y conflictos asociados al descubrimiento adolescente se despliegan en insólito escenario, pues, como indica Moulin Civil, el antagonismo generacional invierte cualquier convención: Ramón, el padre, considera el cuerpo "todo un sacerdocio y hasta una dinastía", mientras a su hijo "le horroriza todo cuanto sea carne [...] palpitante" (Moulin Civil: 45).

Desde un principio, René deberá ubicarse en los márgenes, víctima de doble exclusión: repudia el código sadomasoquista que rige su familia, pero la sociedad lo rechaza por haber nacido en tal hervidero de anomalías y perversiones. En efecto, la extraña "Hermandad de la Carne" a que el clan pertenece sitúa el discurso en lo extraño- inverosímil, recorriendo los límites racionales para construir un delirante mundo al revés.

Semejante marco favorece la inversión del discurso religioso establecido en torno al cuerpo. Como señala Arrufat, la novela erige la carne en sistema teológico, manejando términos como cruzada, sacerdocio, iniciación o culto. Ello establece perversas conexiones con la retórica judeo-cristiana del martirio. En efecto, el catolicismo exalta la carne castigada mediante diversos símbolos patibularios: la cruz, que constituye su centro gravitacional, la retórica eucarística, que transforma cuerpo y sangre en alimento, o la interminable lista de mártires venerados en los altares. Desde la Contrarreforma, además, el culto abstracto da paso a sobrecogedoras iconografías que pretenden inspirar piedad o arrepentimiento enfatizando signos de dolor y tortura.

\footnotetext{
${ }^{16}$ El destacado es nuestro.
} 
En este sentido, la familia de René asume cierta lógica reconocible: la Iglesia recomienda y exalta el castigo del cuerpo, promoviendo ayuno, continencia sexual e, incluso, autolesión. Ello adquiere sentido en el marco del conflicto carne-espíritu: los mártires devienen santos porque anteponen salvación espiritual a seguridad física. Sobre tal base, la novela piñeriana opera claras inversiones: Ramón y su Hermandad defienden el martirio como fin en sí mismo. Para reverenciar el cuerpo, centro de su teología, le suministran placer y dolor, dos estímulos por los que cobra conciencia de sí, imponiéndose al resto de facultades.

Como se observa en "El enemigo", el dolor nos reduce a mera carne sufriente: ante una infección dental o una neuralgia "uno es, además de sí mismo, una muela o una cabeza" (Piñera, 1999: 169). Así, por vía dolorosa rendimos culto al cuerpo, elevándolo sobre toda voluntad o raciocinio. Además, el martirio permite explorar posibilidades de la carne, alterar su color, textura o disposición. Tal es el sentido de la particular fe profesada por Ramón, "un hombre perdidamente enamorado de la carne; tan enamorado que hacía medrar la de su hijo con todo el desvelo posible, para ofrecerla en holocausto a no sabemos qué divinidades ignoradas" (cit. en Moulin Civil: 45). Semejantes nociones permiten, según Moulin Civil, "explorar, hasta los límites, el polisemantismo y el polisimbolismo del término "carne": carne de res y carne humana, carne como metonimia del cuerpo y metáfora del dolor o del placer" (ibid.).

En definitiva, si La carne de René funciona como novela de iniciación o aprendizaje, deberíamos preguntarnos por la didáctica en ella contenida. En realidad, el propio narrador sintetiza toda moraleja cuando exclama: "iQué curioso! Por dos vías tan antitéticas como dolor y placer se arribaba a una desoladora verdad: que la carne era el motor de la vida" (cit. en Moulin Civil: 45). Tal afirmación cuestiona siglos de tradiciones y creencias compartidas, por eso para Arrufat esta novela nos invita "a aceptar, por encima de las concepciones idealistas y el fetichismo del intelecto, una verdad primera: que estamos hechos de carne" (Arrufat, 1990: 47).

Semejantes premisas permiten analizar cuentos protagonizados por la carne en sus variadas acepciones. Ante todo, sus protagonistas suelen asumir lo corporal como herramienta cognoscitiva que permite alcanzar ciertas verdades mediante estímulo doloroso o placentero. No obstante, suelen decantarse por la primera vía. En este sentido, Arrufat observa que "en esta apuesta de Virgilio por el cuerpo hay una ausencia considerable: el sexo" (Arrufat, 1999: 25). Como ejemplo, menciona "El cambio", donde el encuentro amoroso se reduce a la tópica expresión "memorable noche carnal". En su opinión, estas elipsis se explican por la retórica fría que Virgilio esgrime como seña identitaria. Sin embargo, tal asepsia impregna también las experiencias dolorosas, cuya descripción aúna distancia y detallismo.

Existen, pues, mayores motivos para tal exclusión. En primer lugar, debemos recordar el principio de fracaso que, en Piñera, orienta todo esfuerzo comunicativo. Esta consideración se extiende al sentimiento amoroso, asumido como entelequia, patético intento de escapar al absurdo que termina por sumergirnos más en él. Así, el amor deviene pasión egoísta, ya que exige objetualizar al otro. Constituye además, nuevo agente de marginación, excluyendo a todos aquellos que, como se dice en 
"Amores de vista", no portan "el grado de seducción requerido" (Piñera, 1999: 161). Recordemos, en este sentido, que Arrufat define fealdad como relación desacordada con el cuerpo. Tal desajuste signa la carne propia y ajena, privando de amor correspondido.

Así sucede en el mencionado "Amores de vista". En este caso, rechazos y derrotas amorosas construyen el particular infierno del personaje. Éste, sin embargo, ha encontrado un modo de acallar "llamas" y "quejidos": su estrategia erótica pasa por conferir realización literal al manido amor a primera vista (ibid.: 162). Semejante propuesta opera por inversión, excluyendo del vínculo amoroso todo contacto o comunicación. Con una mirada el narrador elige amantes, cifrando su enamoramiento en sucesivos esfuerzos por no exteriorizar emoción alguna. De este modo se sumerge en apasionados idilios. Le basta un simple estímulo visual, pues su imaginación hace el resto: "Yo mismo me pregunto y me respondo; si se me ocurriera hacerla hablar la respuesta sería un no rotundo, pero ¿qué necesidad tengo de arriesgarme cuando de antemano está rendida a mis pies?" (ibíd: 161-162).

Pero en tanto mujer real, esta amada ignorante de su rol, constituye auténtica enemiga, pues su astucia femenina amenaza todo proyecto amoroso: si llega a entrever las intenciones del personaje, querrá frustrarlas con esa negativa rotunda. Por eso nuestro hombre se ha visto obligado a entrenar sus ojos, inventando una mirada impasible cuya frialdad constituye paradójico síntoma de profundo amor. Podría decirse que este cuento reescribe el concepto de fantasía sexual: este fracasado deviene heroico por transformar la ilusión compensatoria en clave existencial. En este sentido, funciona como Sísifo feliz, dispuesto a rebelarse mediante afirmación irónica del absurdo.

"El cambio" también resulta interesante. Aquí sí se produce comunicación placentera entre cuerpos, pero de forma atípica y perversa. Ello proporciona claves fundamentales para comprender el concepto piñeriano de lo erótico. Así, Francisca Noguerol analiza el cuento como parodia de cierto discurso literario:

El mito del amor se degrada por el empleo de clichés literarios tomados de la novela gótica. De este modo, leemos que las respectivas parejas llegan "a la entrada del paraíso humano" a disfrutar del amor "de los eternos amantes hasta ahora separados por las inevitables asechanzas del destino" [...]. La parodia se culmina en una frase que encierra una expresión metaficcional: "los amantes se cumplieron en el amor hasta agotar, como se dice, la copa del placer". (Noguerol: 80)

El presunto sentimiento se revela convención social cargada de tópicos y prejuicios. En este sentido, el "amigo", personaje casi mítico, demostrará lo espurio del amor en tanto construcción ideológica. Ello justifica el intercambio de parejas: los amantes pueden disfrutar de una memorable noche carnal con personas que no han elegido, confiriendo absoluta preeminencia a lo físico-pulsional. Para culminar la hazaña y ahorrar innecesarias culpas, este "amigo" despoja a los enamorados de 
lengua y ojos. ${ }^{17}$ De este modo, y como apunta Noguerol, se asume "el supremo poder de la carne", demostrándose "la inutilidad del lado espiritual del amor" (ibid.: 81).

Aquí la mutilación se ejerce sobre órganos con función intelectual: la mirada, que se proyecta sobre lo real cargada de tradiciones anquilosadas, y la lengua, que articula palabras vacías o agotadas. Estas "partes" devienen enemigas porque no son sólo carne: constituyen ventanas al fatídico Yo, en perpetuo conflicto con su armazón corporal. En este sentido, el cuento ofrece una propuesta inversa a la comentada para "Amores de vista". 18

"Unión indestructible" también plantea alternativas sadomasoquistas al convencionalismo amoroso. En este caso, Piñera parece cuestionar la institución matrimonial: aunque todo va "de mal en peor", la pareja no considera separarse (Piñera, 1999: 163). Ello sugiere cargas sociales y prejuicios morales. De nuevo, la solución pasa por conferir realización creativa a tal absurdo, privilegiando lo corporal en detrimento de lo emotivo-intelectual. Así, la estrambótica decisión de untarse en pez y secarse al sol abrazados constituye respuesta irónica al sinsentido de un futuro juntos.

Por tanto, para Piñera toda experiencia erótica halla pleno sentido al impregnarse de dolor, violencia y agresión compartida. De todo esto constituye síntesis el poema "Solicitud de canonización de Rosa Cagí", que parodia tópicos asociados a la religio amoris: enfermedad de amor, muerte en vida, martirio y santidad. Con ello se erige una "religión del horror", cuyo supremo mandamiento reza "Amarás aunque te muelan a palos".

Ya nos hemos introducido en la dinámica piñeriana absurdo-placer-dolor, aclarando ciertas premisas fundamentales. Analizaremos ahora textos que tematizan la carne torturada en tanto fundamental categoría simbólica. Ellos erigen ese imperio carnal donde cada cuerpo se manipula, segmenta o devora sin piedad alguna. ${ }^{19}$ Allí además se venera lo humano en sus más primarias y grotescas manifestaciones, culto del que "La cena" constituye magnífico ejemplo.

Todo ello remite en más de un aspecto a teorías y prácticas surrealistas. Recogiendo propuestas anteriores, la escuela bretoniana estableció inéditas formas de

${ }^{17}$ Podría establecerse cierta relación con "Los ojos de Lina" (1896) del peruano Clemente Palma, pues en ambos casos la mirada lastra toda comunicación sincera: las pupilas verdes de Lina albergan tal extrañeza amenazadora que la joven deberá sacrificarlas para preservar su amor.

${ }^{18}$ Más narraciones piñerianas exaltan la ceguera. Así, en "Oficio de tinieblas”, la no visión del padre constituye motivo de júbilo y ejemplo para toda la familia. Tal planteamiento revela ciertas conexiones borgianas. "La cara", por su parte, invierte la tópica ecuación alma=rostro. Éste, de hecho, amenaza la amistad entre los protagonistas, por lo que uno de ellos se extraerá los ojos para preservarla.

${ }_{19} \mathrm{La}$ inversión paródica funciona aquí en doble dirección. En primer lugar, existe irreverencia religiosa, pues no se reconoce el cuerpo como recipiente espiritual. Al tiempo, y recogiendo destacadas tradiciones modernas, se reniega del culto burgués por lo higiénico y saludable. 
culto al cuerpo. Éste adquiere valor fundamental en tanto agente revolucionario, liberador de instintos y pulsiones reprimidas. Así, lo bajo-corporal suministra dinámicas críticas contras la episteme burguesa, caracterizada por vivir de espaldas a la carne, en tanto fuente de vergüenza, temor o delito.

En esto autores, lo escatológico, sexual y obsceno constituye idioma habitual y seña identitaria. Aragon, por ejemplo, declara "la victoria de todo lo sórdido sobre todo lo admirable" (cit. en Morris: 26). Así, su programa de revolución integral no excluye conductas desviadas y gestos escandalosos: parafilias, incesto, exhibicionismo o voyeurismo se reivindican con entusiasmo. La mutilación, motivo iconográfico y literario, también figura entre sus preferencias. En este sentido, el ser humano se percibe como maniquí u objeto manipulable: su afición por lo cinematográfico se explica, de hecho, porque permite segmentar el cuerpo, alentando obsesiones fetichistas.

De este modo se pretende suministrar tratamiento de choque al individuo moderno, alienado por la racionalidad instrumental. Con similar propósito se recupera la figura del loco. Pensemos, por ejemplo, en el método paranoico-crítico, formulado por Salvador Dalí. El pintor reconoce ambas categorías, en apariencia contradictorias, como caras de una misma moneda: la locura se aloja en la razón, revelando sus excepciones, carencias o paradojas.

Tal planteamiento resulta fundamental en Virgilio, que reivindica toda conducta periférica en tanto "mueca" a lo convencional. Marta Morello Frosch proporciona interesantes claves al respecto:

en los textos de Piñera se articula y se representa el imaginario diario, se da una representación de una situación anómala pero no extraña a la experiencia humana y se cuestiona la racionalidad del imaginario colectivo. Todo esto se logra a través de un locus muy visible y sensible a la experiencia humana, el cuerpo. [...] Piñera a menudo elige este medio para restaurar esa voz asordinada, y a la vez demuestra la insensatez del discurso de la cordura al apropiarse de su orden y metáforas. (Morello Frosch: 30)

Así, estas narraciones articulan dos discursos complementarios y en estatuto de igualdad. El idiolecto paranoico usurpa lo racional-socializado para aplicarlo en contextos anómalos o transgresores, situaciones límite que revelan sus fallas e insuficiencias. La razón crítica no tiene más remedio que reconocerse en tales esquemas, aunque perciba lo espurio de su aplicación. Tal paradoja deviene puesta en abismo o experiencia de los márgenes: imaginario colectivo y lenguaje cotidiano zozobran ante tal suerte de duda metódica que cuestiona su sensatez, pertinencia y eficacia.

Por tanto, perspectiva demente y canto a lo bajo-corporal constituyen recursos piñerianos de innegable raigambre moderna, más en concreto, surrealista. Ahora bien, en tanto casa de locos, el universo-Piñera tiende a privilegiar lo frío y aséptico: distanciamiento y detallismo quasicientífico generan inconfundibles nociones de angustia. Así, toda experiencia física o emocional resulta atravesada por estrategias absurdistas que, mediante humor negro e ironía, suscitan aterradoras distorsiones de 
lo real. Entre otras cosas, ello se explica por concretas razones históricas, pues, como ya explicamos, Piñera trabaja en años de fracaso y regresión distópica, contexto diferente al que rige la vanguardia histórica.

Con todo, también pueden rastrearse aquí propuestas éticas. Como tantos autores absurdistas, el cubano mantiene estrecho compromiso con su realidad epocal. Pero su particular humanismo abunda en escepticismo y desaliento. En general, el creador post-bélico no pontifica ni ansía constituirse en portavoz de grandes causas: se conforma con mostrar extremos de alienación e ignominia suscitados por ciegas doctrinas de progreso y exclusivos criterios instrumentales. ${ }^{20}$

\section{Un huequito para respirar}

Estas reflexiones fundamentan nuestra lectura de lo corporal en Piñera. Es cierto que sus cuentos, a menudo esquemáticos y acircunstanciados, se prestan a diversas interpretaciones. No obstante, en estas líneas hemos procurado caracterizar al escritor como hijo de su tiempo, sensible a todo problema y obsesión contemporánea. A partir de aquí, pretendemos extraer cierto programa ético o propuesta redentora. Así, entendemos que, mediante violencia y mutilación, Virgilio persigue erigir carne y cuerpo en espacios de libertad y resistencia a lo establecido. Veamos los motivos que conducen a tal conclusión.

Recordemos que Piñera y sus criaturas enfrentan el reto de establecer alguna concordancia armónica entre carne y Yo. Nuestro cuerpo, ese gran desconocido, deviene ajeno por obra de tradiciones, prejuicios sociales y convenciones religiosas. Éstas cimentan lo identitario en esquemas dicotómicos, privilegiando visiones fragmentarias del ser. Ya los surrealistas procuraron solventar tal conflicto reivindicando la carne en su función metafísica o trascendente. Para ellos, todo placer físico constituía herramienta espitemológica. El cubano, por su parte, mantiene premisas similares respecto al dolor. Así puede apreciarse en "El caso Acteón".

El texto confiere valor literal a metáforas y clichés que suelen indicar comunicación sincera o emotiva. Los protagonistas abren su corazón, es decir, se desgarran el pecho para penetrar unos en otros hasta formar "una sola masa, un solo montículo, una sola elevación, una sola cadena sin término" (Piñera, 1999: 43). ${ }^{21}$ Ello podría interpretarse como patético llamado al vínculo sincero, más allá de toda palabra o convención vacía. Estos individuos han comprendido que quizá sólo estén hechos de carne, por ello asumen sus cuerpos como herramienta comunicativa, más

${ }^{20}$ Ello explicaría la insistencia en presentar mundos alucinados y personajes paranoicos. El ciudadano convencional no se percibe así porque modernas nociones de progreso han generado cierta ilusión de normalidad y felicidad permanentes. Los autores absurdistas conciben texto o escenario teatral como gigantesco espejo deformante. Allí el individuo puede contemplar, multiplicados, los síntomas y efectos de su enajenación.

${ }^{21}$ Conforme el narrador se sumerge en la cadena Acteón, va desapareciendo toda acotación al diálogo. De este modo, se recrea la fusión de voces en una sola. Tampoco se diferencian conversación y relato, pues, tal como el personaje indica, "mi voz correspondía a su acción; su acción, a mi voz" (Piñera, 1999: 43). 
reconocible y eficaz que cualquier presunción metafísica. Y, en efecto, no puede concebirse mejor forma de encuentro que la aquí propuesta.

Ello explica que no teman el dolor, como tampoco lo hace el excéntrico vecino del narrador en "Las partes". De nuevo, encontramos dos criaturas desarraigadas y solitarias: viven en una casa de huéspedes, emblema de anonimato, quedando sus cuartos separados por un simbólico corredor "de grandes proporciones". Semejantes distancias se salvarán por vía corporal: el misterioso hombre de la capa consigue intrigar al vecino, que terminará por responder, conmovido, a su reclamo. Con sucesivas entradas y salidas, cada vez despojado de un nuevo miembro, el personaje reclama ayuda para completar su peculiar collage. Parece haber asumido lo inútil e insuficiente del idioma colectivo, por lo que recurre a su particular lenguaje corporal, única realidad que posee y, por tanto, puede entregar. Por su parte, el narrador resulta atrapado en tal dinámica. Así, cuando el vecino no reaparece para mostrar, por octava vez, los resultados de su misterioso experimento, se "lanza furiosamente" contra la puerta, atravesando, por fin, el enorme corredor. La imagen del vecino crucificado deviene entonces experiencia redentora: "Complaciéndolo de todo corazón, tomé con delicadeza aquella cabeza por su cuello y la fijé en la pared con uno de esos pernos enormes" (ibid.: 45). ${ }^{22}$

Semejante encuentro adquiere dimensión catártica para estas existencias enajenadas: su breve intercambio ha burlado todo obstáculo físico y social capaz de alejarlos. Por eso el narrador puede colocarse la misteriosa capa, símbolo de empatía, "para salir como un rey por la puerta" (ibid.). ${ }^{23}$

Por tanto, Virgilio reivindica la carne como única verdad y constante existencial. Perdido todo asidero ideológico, social o metafísico, el individuo constata su ontología como tragedia y absurdo. Su cuerpo, sin embargo, lo sustrae a la nada cada vez que respira, siente hambre, dolor o frío. Por eso, constituye espacio de libertad susceptible a cualquier manipulación creativa. En este sentido, los personajes piñerianos jamás se agreden o mutilan sin propósito bien definido. Éste se expone, además, con lógica irreprochable, esgrimiendo aquellas mismas armas que invocaría la razón para condenarlo.

Como resultado, surgen profundos interrogantes: actividades cotidianas devienen tan absurdas como esas experiencias límite que, sin embargo, proporcionan al personaje piñeriano ciertas dosis de felicidad. En los casos comentados, la realización personal opera por encuentro con el otro, conforme premisas sartrianas. A continuación, analizaremos "La caída", donde mutilación y vínculo físico permiten burlarse de la muerte, máximo sinsentido existencial. ${ }^{24}$

${ }^{22}$ El destacado es nuestro.

${ }^{23}$ Este final completa bien el precario hábitat construido por Piñera: la ironía funciona como higiénica distancia, neutralizando sentimentalismos fáciles.

${ }^{24}$ La muerte constituye tema habitual en Piñera. Ante todo, le preocupa que un fenómeno natural se torne convencionalismo o herramienta de manipulación religiosa. Significativo 
Desde la primera línea, se introducen planteamientos absurdistas: el presunto hecho memorable (dos hombres ascienden una montaña de tres mil metros) se sintetiza en rápido y aséptico comentario. La hazaña se producirá al descender los personajes en caída heroica, pues ello permitirá reescribir un destino tan fatal como absurdo. En este sentido, resulta evidente la referencia a Sísifo. Sabiéndose perdidos, los escaladores deciden, con lógica sorprendente en tales circunstancias, conferir sentido al patético desenlace: la caída habrá merecido la pena si uno salvaguarda sus ojos y el otro su barba. Así no cabrán "lamentaciones", pues, como indica el narrador, cuando sus ojos lleguen "sanos y salvos al césped de la llanura" podrán contemplar "la hermosa barba gris" del compañero, resplandeciendo "en toda su gloria" (ibíd: $37)$.

A partir de aquí, ambos personajes consagran toda energía a salvaguardar estas partes. Ello torna la caída en fraternal sacrificio: sufrir horribles mutilaciones resulta nimio inconveniente ante la magnitud de su propósito. Por eso el narrador detalla el fatal descenso con científica frialdad, permitiéndose, incluso, bromear: "Aproximadamente a unos diez pies de la llanura la pértiga abandonada de un labrador enganchó graciosamente las manos de mi compañero" (ibíd.: 36).

En definitiva, como apunta Morello Frosch: "la muerte final, si bien ineludible, representa un pequeño triunfo de la voluntad de estos dos despeñados", pues "se reitera el poder de una conciencia dirigida hacia la preservación de vestigios corporales, como antídotos de la angustia y el dolor y como mínima y demencial posibilidad de subsistir" (Morello Frosch: 34-35).

En este sentido, Piñera cuestiona el principio de lo inútil, atroz categoría racional. Ojos y barba no sirven de mucho perdidos los restantes miembros. Pero preservarlos constituye aquí supremo acto de libertad: lo personajes desafían la muerte en su potencial impositivo, procurando hacerla suya. Así, en contexto tan poco propicio logran perecer de forma solidaria y creativa. En este sentido, recordemos que el hombre posee todo derecho sobre su cuerpo, pudiendo decidir qué partes del mismo le interesan en cada momento. En fin, esta "caída" alberga importante dimensión simbólica. Así, parece compensar el principio bíblico de pecado (caída) original con el culto moderno a Satán (ángel caído).

Por último, analizaremos "La carne", episodio de locura colectiva que invierte cualquier jerarquía lógica y moral. ${ }^{25}$ Aquí la fiebre corporal afecta a todo un pueblo que reacciona de forma inverosímil ante determinada carestía alimentaria: cuando faltan productos cárnicos deciden echar mano de reservas personales. De nuevo el absurdo proporciona claves de rebeldía o libre albedrío: devorar el propio cuerpo equivale a desafiar todo azar y desamparo existenciales. Como apunta Morello Frosch:

ejemplo constituye "Alocución contra los necrófilos", poema de 1974. Sus opiniones en este terreno guardan claro parentesco con las expresadas por Oliverio Girondo en Espantapájaros.

${ }^{25}$ El relato maneja técnicas de blow-up, habituales en la literatura absurdista. 
la locura permite a los ciudadanos un último gesto de independencia. Pues se vive dentro de los parámetros que la situación provee, pero la imaginación y una considerable dosis de estoicismo permiten que los hombres puedan elegir la forma de su sacrificio y de su muerte. La locura les abre un espacio social desde el cual el loco se convierte en juez de la razón oficial, y hace posible una heroica aunque inútil oposición. (ibíd.: 36)

Frente a "La caída", aquí la mutilación se ejerce de forma deliberada y voluntaria. Pero ello plantea cierta paradoja, pues el cuerpo se sacrifica en beneficio de sí mismo. ${ }^{26}$ Semejante ironía aporta claves fundamentales: la carne constituye único asidero existencial y su preservación justifica cualquier medida extrema, incluidas técnicas de retroalimentación.

El cuento también admite lectura de tipo político. Piñera parodia el discurso cívico, impostando una retórica pseudodemocrática. Esta interpretación se adecua a su visión nacional. Según ya vimos, el autor lamenta vivir en un país paralizado e inmaduro: el periodo pre-revolucionario se percibe como suerte de circo, abundante en gestos autoritarios y palabras vacías. En este sentido, para Diana Sorensen "La carne" analiza el caos relacional Sujeto-Estado-Ley:

En "La carne" el discurso de la virtud cívica produce la nada por desaparición de cuerpos [...]. Adelantándose en décadas al horror de los desaparecidos, Piñera imposta la retórica del patriotismo ante la emergencia nacional y presenta un pueblo que se alimenta de su propia carne en gloriosos espectáculos cuyos méritos de elegancia y buena organización merecen las alabanzas del alcalde. [...] Más respetado pero igualmente inefectivo es el "perito en desaparecidos" [...]. Y es que en Piñera los funcionarios por medio de quienes circula el poder o se topan con excrementos o como en el caso de "El señor Ministro" [...] acaban en la "gran cocina" $[\ldots]$. (Sorensen: 57-58)

Por supuesto, Virgilio suele considerar inútil, cuando no alienante, cualquier sistema de intervención en lo privado-cotidiano: así lo demuestran textos como "La gran escalera del Palacio Legislativo", "El señor Ministro" o "El muñeco". Pero en el caso que nos ocupa, la lectura política, si bien posible, no puede reclamarse única. El cubano mimetiza el discurso patriótico para aplicarlo a situaciones límite que lo desbordan y revelan absurdo. Pero la acción ciudadana adquiere distinta dimensión, pues la antropofagia también permite desafiar toda condición o retórica preestablecidas.

${ }^{26}$ Ello explicaría el polisemantismo del título: la carne humana, de la que se dispone en abundancia, se equipara con la carne animal, de la que se carece. 


\section{Conclusión}

A lo largo de estas líneas hemos procurado analizar engranajes fundamentales del universo piñeriano. Carne y locura funcionan en él como categoría simbólica y principio narrativo. De hecho, sustentan cierto recurso emblemático del estilo-Piñera: conferir sentido literal o realidad física a metáforas y clichés cotidianos. ${ }^{27}$ En este sentido, apunta Morello Frosch:

¿Cómo habla un texto desde la locura? Piñera lo hace apropiándose de una lengua que, si bien familiar, nos permite recuperar lo extraño. Esta lengua comparte muchos de los conceptos de la lengua diaria, pero tiene también su propio sistema de pensamientos que condicionan lo pensable, de modo que si bien las palabras en general son sensatas, están enmarcadas en condicionamientos totalmente irracionales y producen así una especie de defecto de traducción, como diría Freud, como algo que es perfectamente inteligible pero cuyo funcionamiento es defectuoso [...]. Así Piñera hace mucho más evidente la paradoja subyacente en gran número de las metáforas de uso diario, al aplicarlas estrictamente a una realidad que no las encarna. (Morello Frosch: 33)

De todo ello encontramos abundantes ejemplos. Así, mientras los personajes de "La cena" viven del aire, los de "La carne" se chupan los dedos. La "Unión indestructible" no puede serlo más, dados los términos en que se produce. Por su parte, los protagonistas de "El caso Acteón" deciden "abrir sus corazones" en sentido literal. En fin, cuentos como "El gran Baro" y "El muñeco" ofrecen muestra elocuente de lo que significa ser un payaso o un pelele, sobre todo en materia política.

Lo expuesto otorga a Piñera lugar privilegiada en toda genealogía literaria de locos, excéntricos y marginales. Tales categorías han revelado, además, especial pertinencia en los estudios latinoamericanos. De hecho, diversos autores actuales esgrimen poéticas periféricas como seña identitaria: pensamos en etiquetas como realismo sucio, cyberpunk o neobarroso. Ello confiere absoluta actualidad al cubano, tornándolo referente fundamental. En este sentido y para terminar quisiéramos evocar unas palabras del también cubano Pedro Juan Gutiérrez:

Ése es mi oficio: revolcador de mierda. A nadie le gusta. ¿no se tapan la nariz cuando pasa el camión colector de basura? [...] Por eso tampoco me sonríen y miran a otro lado cuando me ven. Soy un revolcador de mierda. Y no es que busque algo entre la mierda. [...] No puedo decirles "Oh, miren, encontré un brillante entre la mierda, o encontré una buena idea entre la mierda, o encontré algo hermoso". No es así. Nada busco y nada encuentro. Por tanto, no puedo demostrar que soy un tipo pragmático o socialmente útil. Sólo hago como los niños; cagan y después juegan con su propia mierda, la huelen, se la comen, y se divierten hasta que llega mamá,

27 En este sentido, Virgilio evoca ciertas nociones de Lingüística Antropológica. Con frecuencia, el ser humano toma su propio cuerpo como referente para construir metáforas que tornen mensurable lo real. 
los saca de la mierda, los baña, los perfuma, y les advierte que eso no se puede hacer. (Gutiérrez: 104-105)

\section{BIBLIOGRAFÍA}

AGuILÚ DE MURPHY, Raquel.

1989 Los textos dramáticos de Virgilio Piñera y el teatro del absurdo. Madrid: Pliegos.

BERMAN, Marshall.

1991 Todo lo sólido se desvanece en el aire. Madrid: Siglo Veintiuno de España Editores.

CALINESCU, Matei.

2003 Cinco caras de la modernidad: modernismo, vanguardia, decadencia, kitsch, posmodernismo. Madrid: Tecnos.

FOUCAULT, Michael.

1991 Historia de la locura en la época clásica. Madrid: Breviarios del Fondo de Cultura Económica.

GUTIÉRREZ, Pedro Juan.

1998 Trilogía sucia de La Habana. Barcelona: Anagrama.

MORRIS, C.B.

2000 El surrealismo y España (1920-1936). Madrid: Austral.

OviEDO, José Miguel.

1992 Antología crítica del cuento hispanoamericano del siglo XX (19201980), Tomo I: Fundadores e innovadores. Madrid: Alianza

PARIENTE, Ángel. Editorial.

1996 Diccionario temático del surrealismo. Madrid: Alianza Editorial.

PHILLIPS-LÓPEZ, Dolores (comp.).

2003 Cuentos fantásticos modernistas de Hispanoamérica. Madrid: Cátedra.

PIÑERA, Virgilio.

1990 Virgilio, tal cual. Unión [Revista de la Unión Nacional de Escritores y Artistas de Cuba], Número Especial. La Habana, no 10, Año III, Abril-Mayo-Junio.

1999 Cuentos completos. Ed. de Antón Arrufat. Madrid: Alfaguara.

RoAs, David (comp.).

2001 Teorías de lo fantástico. Madrid: Arco/Libros.

CerverA, Vicente, Morello Frosch, Marta, Moulin Civil, Françoise, NoGUEROL, Francisca, SORENSEN, Diana et al.

1996 En torno a la obra de Virgilio Piñera. Poitiers: Centre de Reserches Latino-Americaines de l'Université de Poitiers. 